\title{
瀬戸内海西部の重力異常と負異常帯の地下構造
}

\author{
愛媛大学理学部地球科学教室* 大 野 一 郎 \\ 金沢大学理学部地学教室** 河 野 芳 輝 \\ 東京大学海洋研究所*** 藤 本 博 巳・小泉金一郎
}

\section{Gravity Anomaly in and around the Western Seto Inland Sea and Subsurface Structure of Negative Anomaly Belt}

\author{
Ichiro OHNo
}

Department of Earth Sciences, Faculty of Science, Ehime University, Bunkyou-cho 2-5, Matsuyama 790, Japan

\section{Yoshiteru Kono}

Department of Earth Sciences, Faculty of Science, Kanazawa University, Kakumamachi, Kanazawa 920-11, Japan

\author{
Hiromi Fujımoto and Kin-ichiro Koizumi \\ Ocean Research Institute, University of Tokyo, Minamidai 1-15-1, Nakano-ku, Tokyo 164, Japan \\ (Received July 28, 1994; Accepted November 7, 1994)
}

\begin{abstract}
Both sea surface and land gravity measurements have been carried out in and around the western Seto Inland Sea, southwestern Japan. Both kinds of data were combined to prepare a Bouguer anomaly map. The map shows that there exists in the western Seto Inland Sea a belt of intense negative gravity anomaly with a maximum of $-60 \mathrm{mgal}$, elongated in $\mathrm{SW}-\mathrm{NE}$ direction from the east of Beppu Bay to off Matsuyama. Based on the seismic reflection profiles obtained in the east of Beppu Bay by Yusa et al. (1992), cross sections of the negative gravity anomaly belt were analyzed by Talwani's method. The results indicate the existence of a graben structure buried with low-density sediments along the negative gravity anomaly belt.
\end{abstract}

Key words: Seto Inland Sea, Gravity anomaly, Negative gravity anomaly belt, Ryoke belt, Sambagawa Belt.

§1.はじめに

ここ十数年の間に, いくつかの研究機関により日本列 島の密な重力測定が行われ, 詳細な重力異常分布が明ら かにされてきた[河野・古瀬(1989), GRAvity RESEARCH GROUP IN Southwest JaPAN (1994)]. しかし, その中で重力デー夕の空白域として残されたところああ る. 瀬戸内海もその一つである.この空白を埋めるべく,

* 7900 松山市文京町 2 番 5

** $\overline{\mathrm{T}} 920-11$ 金沢市角間町

*** 于164 東京都中野区南台 1 丁目 15-1
1991 年 7 月に東京大学海洋研究所の淡青丸の KT-9110 次航海により, 瀬戸内海の海上重力測定が実施され た [小泉・他 (投稿中) ].

一方，OHNo et al. (1989) は陸上重力測定を四国北西 部で行い, その後も爱媛県, 広島県, 山口県, 大分県の 瀬戸内海沿岸部, 及び瀬戸内海西部の数十の島で陸上重 力測定を行ってきた.

この論文では, 上述の海上, 及び陸上重力データを合 わせて，瀬戸内海西部地域のブーゲー異常分布を明らか にする. また, その結果判明した, 中央構造線の北側に 沿った特徴的な負異常帯の地下構造モデルを検討する. 


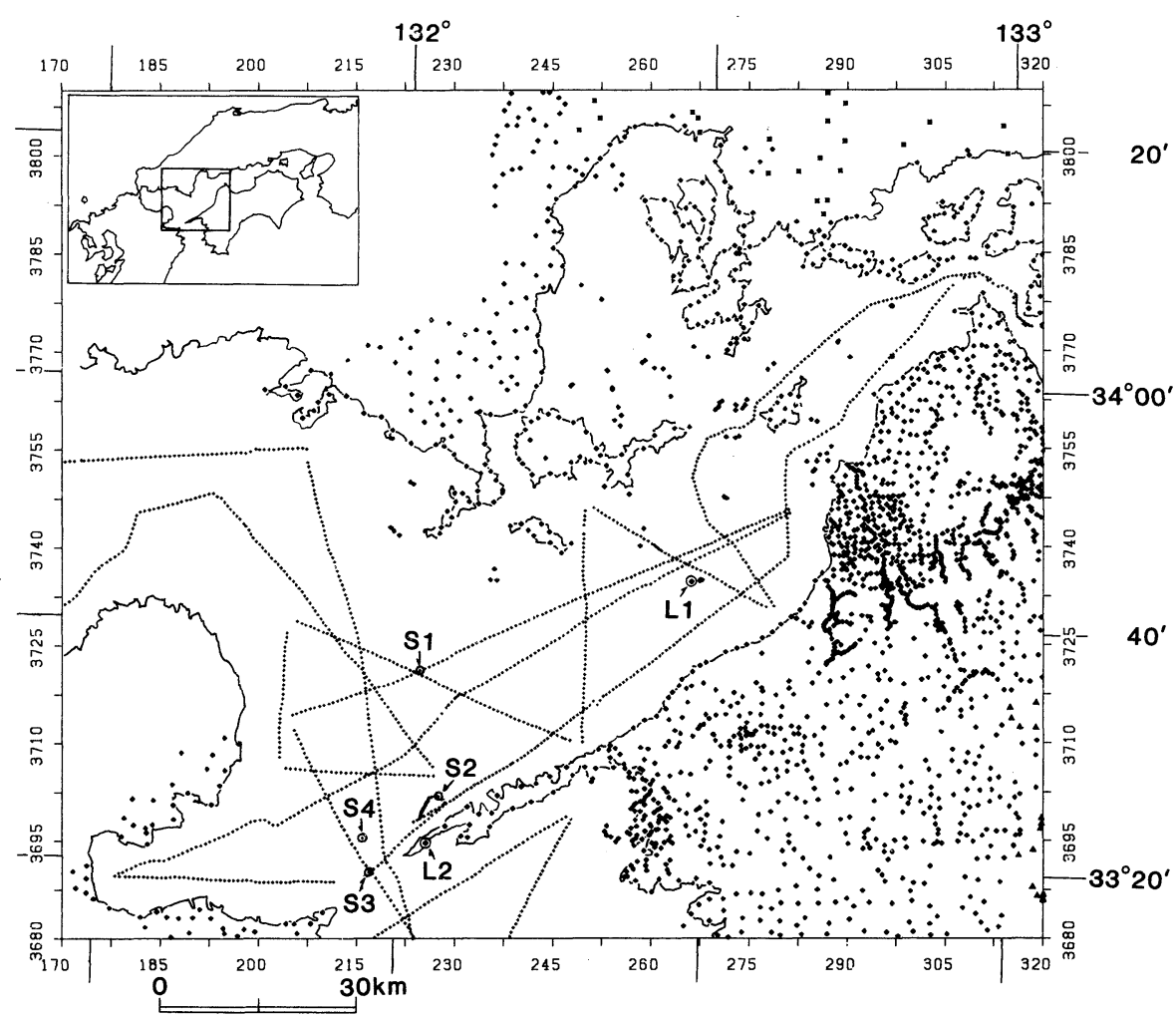

Fig. 1. Index map and distribution of gravity stations.

\section{§2. 重カデータと重力補正}

重力測定点の分布を Fig. 1 に示す.

\section{1 海上データとその重力補正}

Fig. 1 の測定点のうち海上の点は, 前述のように淡青 丸 KT-91-10 次航海によるものであり, TSSG 船上重力 計が用いられた. 重力絶対値は, 神戸港および高松港に おいて, ラコステ $\mathrm{G}$ 型重力計により既存の重力点との重 力結合を行うことにより決定された [小泉・他（投稿 中)]. 航跡が交差する点が Fig. 1 の範囲で 32 点あり, このうち $50 \%$ の点で 2 回の測定值の差 (cross over error, 以下 COE) が $3 \mathrm{mgal}$ 以下, $75 \%$ の点で $5 \mathrm{mgal}$ 以下である。この COE は, 陸上測定の精度と比べると 数十倍大きいが, 海上測定においては, 測位の誤差, 船 の速度や進路のふらつきによるエトベス補正の誤差など により，やむをえない，この COE 調整する交点コン トロール法などは行なっていない，得られたブーゲー異 常分布 (Fig. 2 参照) において, 航跡に沿って海上のコ

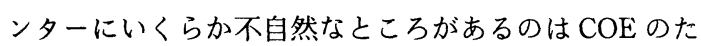
めかむしれない. しかしながら, Fig. 2 はコンター間隔 が 5 mgal でああり，かりにCOE の調整を行なってむ， ブーゲー異常分布のパターンが変わってしまうことはな
いと考えられる．とくに後述の負異常帯の存在は確かな 事実である.

海上の測定値に対しては, 次の (1) 式で単純ブーゲー 異常 $\Delta g$ を求めた：

$$
\Delta g=g+B_{\mathrm{S}}\left(\phi_{0}, \rho-\rho_{\mathrm{w}}, D\right)-\gamma,
$$

ここで $g$ はエトベス補正をした重力測定值， $\gamma$ は正規重 力值である. $B_{\mathrm{S}}$ は周囲の海水 (密度 $\rho_{\mathrm{w}}$ )を, 平均密度 $\rho$, 厚さ $D$ (水深) の球帽で置き換えたときの引力の差を, 萩原 (1975) の球面ブーゲー補正の式で計算したもので ある. 球帽の半径は，次に述べる陸上デー夕の補正と同 じになるよう，孤長 $\phi_{0}$ にして $0.5^{\circ}$ とした. $\phi_{0}=0.5^{\circ}$ では ほとんど

$$
B_{\mathrm{S}}=2 \pi G\left(\rho-\rho_{\mathrm{w}}\right) D
$$

である.ここで $G$ は万有引力定数である，また，平均密 度は $\rho=2.67 \mathrm{~g} / \mathrm{cm}^{3}$, 海水の密度は $\rho_{\mathrm{w}}=1.03 \mathrm{~g} / \mathrm{cm}^{3}$ を 用いた。

(1) 式では, 測定点周辺での水深の变化や陸地の影響 は考慮されていない。これらを考慮したなら，(1)式によ る単純ブーゲー異常への補正がどの程度になるかを, 次 のようにして見積った. Fig. 1 の S1〜S4 の 4 点につい て, 海上保安庁発行の海図から半径 $15 \mathrm{~km}$ の範囲で水 
深を読み取り，またこの範囲で陸地にかかればその地形 補正もして, (1) 式への補正量を求めた. その結果を Table 1 に示す. この海域の水深はほとんどの場所で数 十 $\mathrm{m}$ と浅く，また海底は平坦に近く，そのような測定点 での (1) 式への補正量は, Table 1 の S1, S2 に対する值

Table 1. Correction to simple Bouguer anomaly, eq. (1), when terrain correction for sea bottom topography, and land topography if included, is carried out within a radius of $15 \mathrm{~km}$.

\begin{tabular}{ccc}
\hline Station & $\begin{array}{c}\text { Water depth } \\
(\mathrm{m})\end{array}$ & $\begin{array}{c}\text { Correction to eq.(1) } \\
\text { (mgal) }\end{array}$ \\
\hline S1 & 58 & 0.0 \\
S2 & 90 & -0.1 \\
S3 & 106 & 1.3 \\
S4 & 300 & -2.2 \\
\hline
\end{tabular}

のように $0.1 \mathrm{mgal}$ のオーダーと見積られ, 十分に小さ い. S3, S4 地点における (1) 式への補正量は, 半径 15 $\mathrm{km}$ の範囲でも 1〜2 mgal になる.これは S3, S4 付近 の豊予海峡は, Fig. 1 の海域では例外的に水深の変化が 激しいためである (最高水深 $450 \mathrm{~m}$ ). しかしこれは, 上 に述べた航跡の交差点での測定值の差と同程度であり, さして問題ではない.よってここでは, 海上の測定点に 対しては (1) 式による単純ブーゲー異常を用いることに する。

\section{2 陸上データとその重力補正}

Fig. 1 の陸上の測定点の大部分は, 愛媛大学による測 定であり, OHNo et al. (1989) のもの屯含めて約 2100 点 ある. また, 金沢大学および高知大学による測定点む, それぞれ十数点含まれている. いずれもラコステ G 型重 力計による測定である.

今回の陸上測定においては, 瀬戸内海のうち愛媛一山 口県境付近の島嶼部 (防予諸島), および愛媛一広島県境

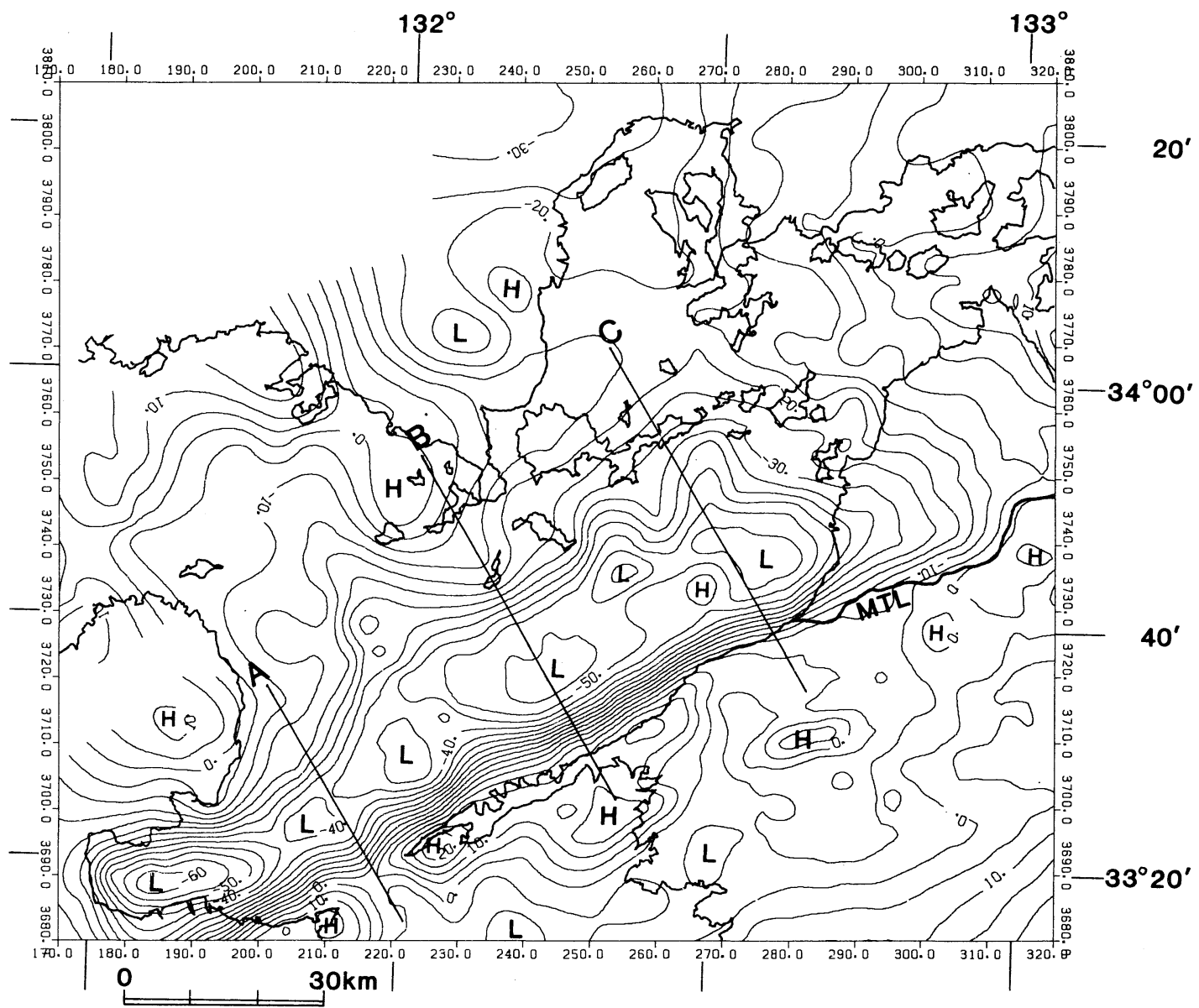

Fig. 2. Contour map of Bouguer anomaly for correction density $\rho=2.67 \mathrm{~g} / \mathrm{cm}^{3}$. Contour interval is 5 mgal. Lines A, B and C indicate the location of profiles referred in Figs. 3, 4 and 5. 
付近の島嶼部（芸予諸島）での測定にも力を注いだ。こ のうち, 船便の無い 13 の小島の測定では, 愛媛大学理 学部附属臨海実験所の協力を得て, 同所の実習船を使用 した.これら島嶼部での測定は, 今回見出だされた負異 常帯（後述）の北東の縁を決める貴重なデー夕をむたら している.

陸上の測定值に対しては, OHNo et al. (1989) と同じ 重力補正, 即ち, 弧長 $\phi_{0}=0.5^{\circ}$ の範囲の球面ブーゲー補 正と, 測定点を中心とする $100 \mathrm{~km} \times 100 \mathrm{~km}$ の範囲の 地形補正を行なってブーゲー異常を求めた. 補正密度は $2.67 \mathrm{~g} / \mathrm{cm}^{3}$ とした.

地形補正において, 上述の範囲内でもそこが海であれ ば地形補正は行っていない，そこでここでは, 海域に対 する地形補正の省略の影響がどの程度であるかを調べ た.この影響が最む大きいとみられる測定点の代表とし て, Fig. 1 の L1, L2 の 2 点について, 海図から水深を

Table 2. Densities and density contrasts used in this study.

\begin{tabular}{ccc}
\hline \hline Geological unit & $\begin{array}{c}\text { Density } \\
\left(\mathrm{g} / \mathrm{cm}^{3}\right)\end{array}$ & $\begin{array}{c}\text { Density contrast } \\
\left(\mathrm{g} / \mathrm{cm}^{3}\right)\end{array}$ \\
\hline $\begin{array}{c}\text { Sambagawa belt } \\
\text { basement (SB) }\end{array}$ & 2.87 & $\begin{array}{c}0.00 \\
\text { (reference) } \\
\text { SB in section B }\end{array}$ \\
$\begin{array}{c}\text { Sediments } \\
\text { of graben (Sd) } \\
\text { Ryoke belt } \\
\text { basement (RB) }\end{array}$ & 2.95 & -0.08 \\
Unknown \\
formation (UF)
\end{tabular}

読み取り, 半径 $15 \mathrm{~km}$ の範囲で海水を密度 $2.67 \mathrm{~g} / \mathrm{cm}^{3}$ の岩石で置き換える補正を行った．その結果，L1, L2 に ついての補正量は，それぞれ $0.14 \mathrm{mgal}, 0.20 \mathrm{mgal}$ で あった.よって, 海域の地形補正をしていないことの影 響は十分小さいといえる。これは，この付近の水深がほ とんどの場所で $100 \mathrm{~m}$ 以内と浅いためと考えられる.

§3. ブーゲー異常分布, とくに負異常帯について

82 に述べた重力補正を行なって得られたブーゲー異 常のコンター図をFig. 2 に示す。コンター間隔は 5 mgal である. 海岸部においてコンターは不自然になる ことなくつながっていて, 海上データと陸上デー夕に大 きなくいちがいが無いことを示している.

Fig. 2 の範囲の大部分は, 日向灘から九州東部, 豊後 水道, 四国北西部, 瀬戸内海西部, 山口県, 広島県にか けて広がるブーゲー異常が負の地域 [TOMODA (1973), GEOGRAPHYCAL SURVEy InSTITUTE (1985), 河野・古瀬 (1989)] の内にあり，負異常を示している.

Fig. 2 にみられる最大の特徴は, 図の中央部を東北東 から西南西に, 即ち松山沖から別府湾に伸びる, 幅 20〜 $30 \mathrm{~km}$ の顕著な負巽常帯である. その中軸部でのブー ゲー異常值はー40〜-60 mgal に達している. その南側 は, ブーゲー異常の水平勾配が約 $7 \mathrm{mgal} / \mathrm{km}$ の著しい 急変帯で区切られている。 また北側は $3 \mathrm{mgal} / \mathrm{km}$ 程度 の勾配で区切られている（Fig.2, および断面図 Figs. $3 a-5 a)$.

由佐・他 (1992) は別府湾の反射法地震探查と重力測 定を行ない, 別府湾口から豊後水道にかけて, 深い地溝,

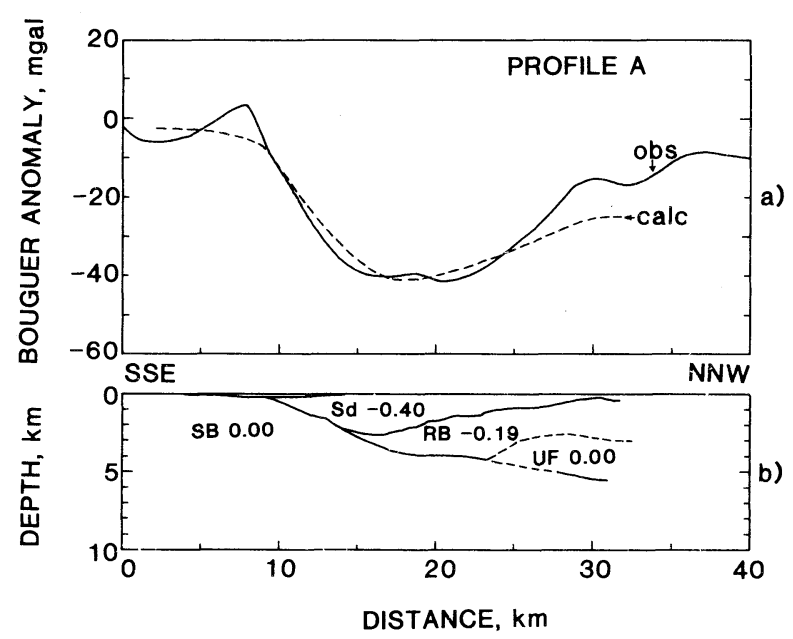

Fig. 3. a) Bouguer anomaly profile calculated for the density structure shown in b) (broken line), compared with the observed profile A (solid line). b)The structure determined by seismic reflection by YusA et al. (1992) (line-J). SB: Sambagawa belt basement, RB: Ryoke belt basement, Sd: sediments, UF: unknown formation. Numerals denote density contrasts in $\mathrm{g} / \mathrm{cm}^{3}$. 


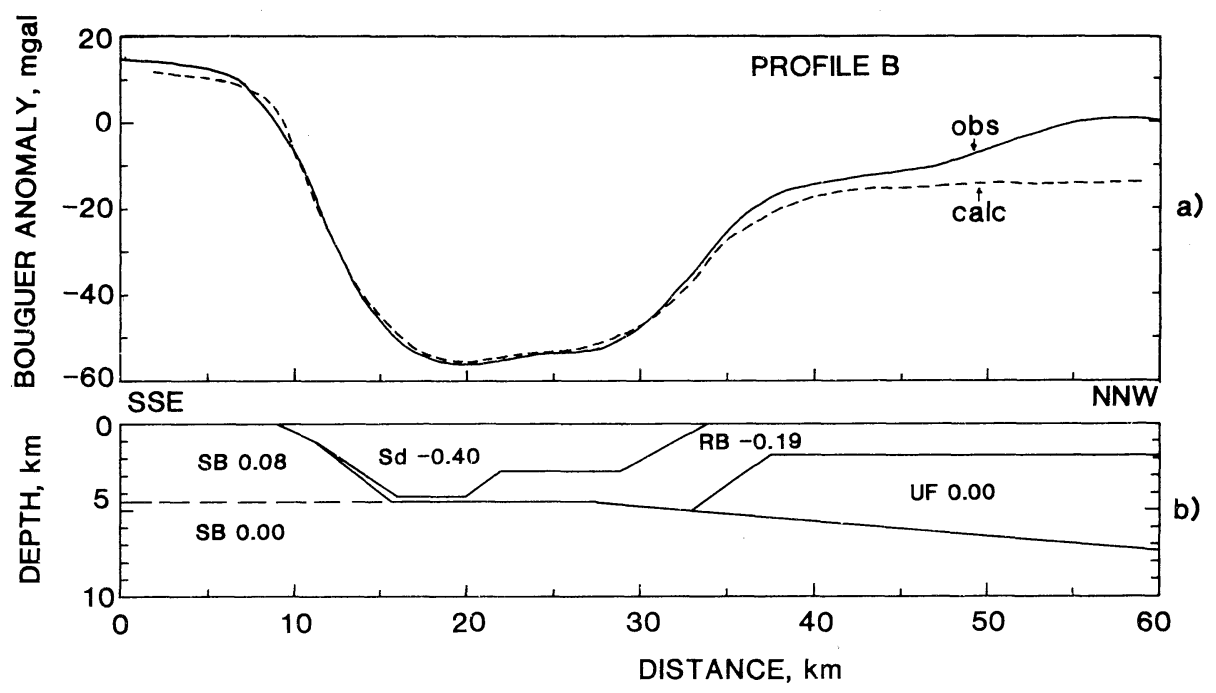

Fig. 4. a) Bouguer anomaly profile calculated for the model shown in b) (broken line), compared with the observed profile B (solid line). b) A model to explain the observed profile B. Legend of the figure is referred to Fig. 3.

および東北東に細長く伸びる負の重力異常が存在するこ とを明らかにした。一方 OHNo et al. (1989) は四国側の 松山地域にも負異常があり，その南側は中央構造線に沿 う重力急变帯によって区切られていることを報告してい る.しかし，この九州側と四国側の負異常がつながって， Fig. 2 のような細長く伸びた顕著な負異常帯を形成して いることは, 今回初めて明らかになった。このことから， 低密度の堆積物で埋められた地溝帯が別府湾東部から松 山沖まで, 約 $100 \mathrm{~km}$ の長さにわたって続いていると考 えられる.

由佐・他 (1992) は, 反射法地震探查と詳細な海底重 力測定により, 別府湾西部の負異常は, 湾東部より東の 地溝構造とは明瞭な構造線で区切られた盆状構造による あのであることを示している. Fig. 2 においても別府湾 内の負異常は，その強さにおいても，コンターの形状に おいて屯，それより東の負異常とはやや異なって現れて いる.

\section{§4. 負異常帯の地下構造}

ここでは，§3 に述べた顕著な負異常帯に焦点を絞 り，代表的な断面 A, B, C (Fig. 2 参照) をとって地下構 造を検討する。

由佐・他 (1992) の反射法地震探查の結果によれば, 別府湾東部から豊予海峡北部においては, Fig. $3 \mathrm{~b}$ に示 すように，三波川帯 (SB) が領家帯 (RB) の下に位置す る. そしてこれらを基盤として, 堆積物 (Sd) で埋められ た地溝が存在する.SBの上面の傾斜は浅いところで約 $30^{\circ}$ ，深いところではより緩傾斜となっている．また $\mathrm{RB}$ の下部には, SB と同程度の密度をもつ未知層 (UF) の存 在が示唆されている.

\section{1 岩石密度}

ここでは, 地溝堆積物 (Sd), 領家基盤 (RB), 三波川基 盤 (SB) の密度を, 由佐・他 (1992) に従って, それぞれ $2.47 \mathrm{~g} / \mathrm{cm}^{3}, 2.68 \mathrm{~g} / \mathrm{cm}^{3}, 2.87 \mathrm{~g} / \mathrm{cm}^{3}$ とする. ただし, 断 面 Bにおいては, SBの浅い部分の密度を $2.95 \mathrm{~g} / \mathrm{cm}^{3}$ とした。これは，断面 B の南端付近（愛媛県八幡浜市） に塩基性岩類・超塩基性岩類が，またこれより西方の佐 田岬半島（愛媛県三崎町）にも変はんれい岩が分布して おり [永井・他 (1980)]，このあたりの SB は断面 A, C に比べて高密度であると考えられるためである. 2.95 $\mathrm{g} / \mathrm{cm}^{3}$ という值は, 断面 B の南端の重力異常をほぼ説 明できるように決めた. 未知層 UF の密度は三波川基盤 之同程度と推定されているので, $2.87 \mathrm{~g} / \mathrm{cm}^{3}$ を仮定す る.これら本論文で用いる各地質ユニットの密度差の一 覧表を Table 2 に掲げる.

\section{2 断面 $\mathrm{A}$}

断面 A は由佐・他 (1992) の反射法地震探查の測線 J にほぼ一致するので, その地下構造 (Fig. 3b) に対する 重力異常を TALWANI et al. (1959) の方法で計算し, 観 测されたブーゲー異常と比較したものを Fig. 3a に示 す. 計算值は観測值の特徴をおよそ説明しているといえ る. ただし, 地溝の北側斜面でのブーゲー異常の傾斜は, 計算值が緩すぎる. 


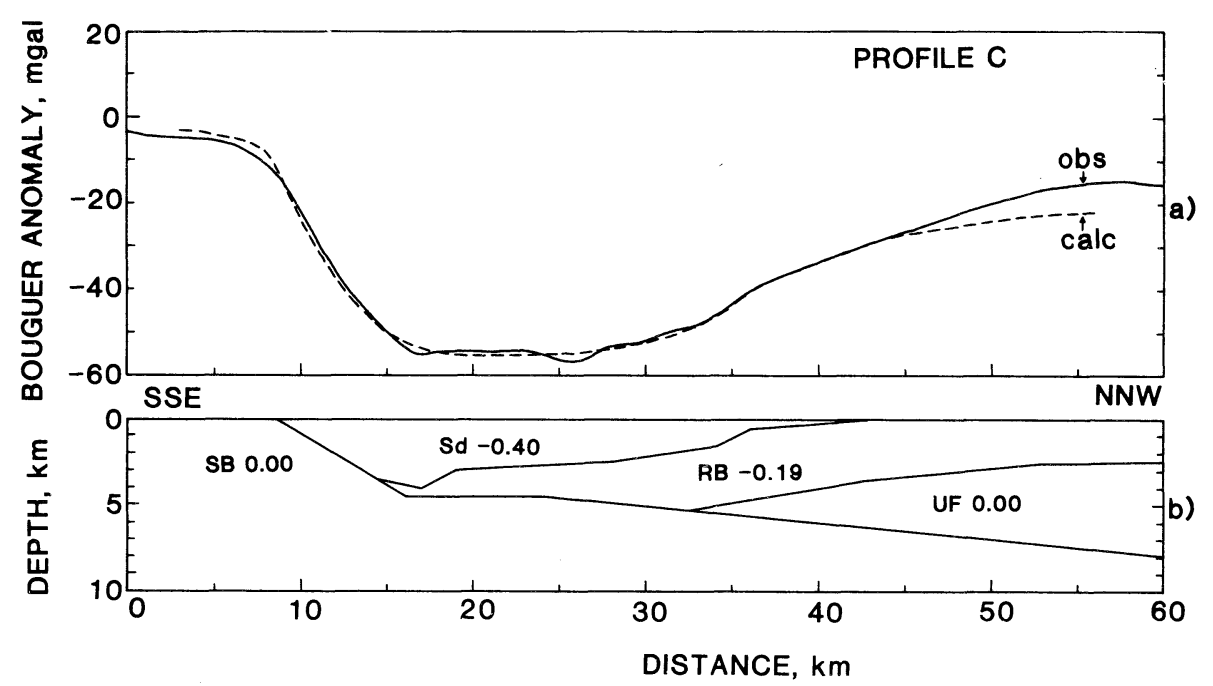

Fig. 5. The same as Fig. 4 for profile C.

\section{3 断面 B}

Fig. 3b の構造から出発して, TALWANI et al. (1959) の方法と試行錯誤とによって，断面 B のブーゲー異常を 説明するモデルを作った。 その結果の構造モデルを Fig. $4 \mathrm{~b}$ に, 重力異常の計算値と観測值の比較を Fig. $4 \mathrm{a}$ に示 す.

Fig. 4b において地溝帯の構造は, 傾斜約 $30^{\circ}$ の南側 の斜面一地溝最深部一平坦部一傾斜約 $30^{\circ}$ の北側の斜面の ようになっている.これは, 次の断面 Cにもみられるの で,この地溝帯の特徴といえょう。地溝の深さは, 最大 で $4000 \mathrm{~m}$ である.

\section{4 断面 C}

同様に，断面 C についての結果を Fig. 5 に示す. 地溝 の深さは, 断面 B と同様, 最大で $4000 \mathrm{~m}$ である. なお, 由佐・他 (1992) が別府湾東部において指摘しているよ うに, 重力異常極小の地点が, 地溝堆積物の厚さ極大の 地点に一致せず, 北にずれていることは注意すべきであ る.このことは，断面 $\mathrm{A}$ に打いてああてはまる.

\section{§5. ま と め}

瀬戸内海西部において海上, 及び陸上重力測定を行な い，ブーゲー異常図を作製した．その結果，松山沖から 別府湾へ細長く伸び, 中軸部で約 $-50 \mathrm{mgal}$ のブーゲー 異常を示す顕著な負異常帯があることが明らかになっ た。この負異常帯の 2 次元断面を説明する構造モデルを TALWANI et al. (1959) の方法で求めた. その際, 由佐・ 他 (1992) の反射法地震探査に上る別府湾東部の地下構 造を出発モデルとした。その結果，Figs. 4b, 5b に示す
ような断面をむつ地溝構造が得られた．地溝の最深部の 深さは $4000 \mathrm{~m}$ である.この地溝構造が四国側の松山沖 から九州側の別府湾東部まで連続し，地溝帯をなしてい ることが明らかになった。

\section{謝辞}

本研究の海上重力デー夕は, 東京大学海洋研究所 1991 年度共同研究 No. 63 （代表：藤本博巳）の淡青丸 KT-91-10 次航海の成果に依っている. 淡青丸の関係者, および同航海に乗船し，観測に協力いただいた富士原敏 也 (東京大学海洋研究所), 志知龍一 (名古屋大学理学 部), 名和一成 (名古屋大学理学部, 現東京大学地震研究 所), 長尾年恭・朝井与志哉 (金沢大学理学部), 井口博 夫 (神戸大学理学部), 中田正夫 (熊本大学理学部, 現九 州大学理学部) の各氏に心から感謝します。

瀬戸内海西部の多数の小島での重力測定の際援助いた だいた金本自由生氏（愛媛大学理学部附属臨海実験所）, 重力データを提供していただいた村上英記氏（高知大 学), 反射法地震探查データに関して貴重な助言をいた だいた井川猛氏（株式会社地球科学総合研究所）に深く 感謝します。

また，永井誠二，暒本重行，片上真一，村上太郎，長 谷川利美, 竹中英之, 曽我部 潤, 迫田英里の諸君には, 卒論の学生として測定とデー夕処理に参加・協力してい ただいた。併せて感謝します。

二人の查読者からいただいたコメントは，原稿の改善 にたいへん役立った，厚く感謝します。 


\section{文献}

Geographycal Survey Institute, 1985, A new Bouguer anomaly map of Japan, Bull. Geogr. Surv. Inst., 29, 102-103.

Gravity Research Group in Southwest Japan, 1994, A Bouguer gravity anomaly map in Central Japan (with a sheet of $1: 700,000$ scale Bouguer anomaly map), Rept. Geol. Surv. Japan, no. 280, 29-36.

萩原幸男, 1975, 通常のブーゲー補正と球面ブーゲー補 正, 測地学会誌, 21, 16-18.

小泉金一郎・藤本博巳 - 井口博夫 - 内津 将 - 河野芳 輝, 瀬戸内海における海上重力測定, 測地学会誌投稿 中.

河野芳輝・古瀬慶博，1989，100 万分の 1 日本列島重力 異常図, 東京大学出版会.

永井浩三・堀越和衛・佐藤信次・宮久三千年・鹿島愛 彦・高橋治郎・土井清麿, 1980, 愛媛県地質図 (第 3
版), トモェヤ.

Ohno, I., K. Takaichi, Y. Endo, R. Goto, A. Takahashi, M. Ishi, S. Okada, Y. Saiki, E. Ohtani and M. Kato, 1989, Gravity survey in northwestern Shikoku, Japan, and subsurface structure of the Median Tectonic Line, J. Phys. Earth, 37, 385-400.

Talwani, M., J. L. Worzel and M. Landisman, 1959, Rapid gravity computations for two-dimensional bodies with application to the Mendocino submarine fracture zone, J. Geophys. Res., 64, 49-59.

Tomoda, Y., 1973, Maps of free air and Bouguer gravity anomalies in and around Japan, Unversity of Tokyo Press.

由佐悠紀・竹村恵二 ・ 北岡豪一・神山孝吉・堀江正治・ 中川一郎・小林芳正・久保寺 章・須藤靖明・井川 猛・浅田正陽, 1992, 反射法地震探査と重力測定によ る別府湾の地下構造, 地震 2, 45, 199-212. 